\title{
Transformation of Exclusive to Inclusive Spaces: The Case of Al-Hikmah 2 Benda Islamic Boarding School, Brebes
}

\section{Agung Kurniawan', Nensi Golda Yuli²}

\author{
${ }^{1}$ Student of the Master of Architecture, Faculty of Civil Engineering and \\ Planning, Universitas Islam Indonesia \\ 2 Department of Architecture, Faculty of Civil Engineering and Planning, \\ Universitas Islam Indonesia
}

\author{
Article History \\ Received : 01 October 2020 \\ Accepted : 12 April 2021 \\ Published : 24 April 2021
}

\begin{abstract}
The history of public recognition of pesantren is closely related to the existence of figures in a pesantren. However, in today's development, various needs and challenges require pesantren to adapt in order to maintain their existence. The increasing number of students followed by various developments in needs and efforts to increase protection are the reason why a number of traditional pesantren transforming their spatial concept. This design transformation was carried out from open (inclusive) to closed (exclusive). On the other hand, this condition has implications for the role of pesantren in community empowerment. This is what happened at the Al-Hikmah 2 Benda Islamic Boarding School, one of the Islamic boarding school that has transformed its space from open to closed. From the existing background, the reasons and objectives of the researcher are to 1). Trace the inclusive and exclusive concepts that have been used by the AlHikmah 2 Benda Islamic Boarding School. 2). Analyze the impact of the application of concepts that have been used on pesantren and society. The research method used is naturalistic, with a key instrument is the researcher. The research results showed that the inclusive and exclusive concepts that have been used by the Al-Hikmah 2 Benda Islamic Boarding School were obtained, as well as the implications of the advantages and disadvantages of applying each of these concepts. Inclusive Islamic boarding schools have advantages in socio-economic interactions and the role of community empowerment but are constrained in efforts to protect students and community recognition, while the concept of exclusive pesantren has advantages in anticipating the protection of students but the role of pesantren in community empowerment is limited. However, there are inclusive spaces found in the exclusive layout of the AL-Hikmah 2 Benda Islamic Boarding School. These spatial concepts and models can be used and developed to deal with problems that arise from the application of each existing concept.
\end{abstract}

Keywords: Community development; exclusive spaces; inclusive spaces; Islamic boarding schools; student's protection.

\section{Introduction}

The social gap becomes a global issue in this contemporary era. This condition appears due to several conflicts on behalf of religions, races, ethnics and social statuses that develop in

Correspondence: Nensi Golda Yuli

Department of Architecture, Faculty of Civil Engineering and Planning, Universitas Islam Indonesia E-mail: nensi@uii.ac.id some countries, in the Middle-East (Cristol, 2018), China (Clarke, 2017), as well as in Indonesia (Agustina, 2018). One of the most effective ways to overcome those issues is by adopting a multicultural education concept (Asmuri, 2017).

From a number of existing multicultural education models, pesantren or Islamic boarding school is one of good multicultural education example (Li, 2013; Muhaemin Latif, 2016) in Indonesia with a number of potentials from student diversity (Nakaya, 2018) quantities 
(Martin, Papworth, Ginns, \& Liem, 2014), as well as its history as the first traditional education in Indonesia (Yuli, Haningsih, \& Adikrishna, 2011) therefore the Islamic boarding school, should also be able to adapt upon issues, conditions and requirements of current developments (Kusnadi, Sobur, \& Aziz, 2017) to maintain its existences through community development roles (UU Pesantren No. 4, 2019) as well as students protection upgrades (Cranfield, 2015). The purpose of this research is to explore the inclusive and exclusive concepts that have been used by the Al-Hikmah 2 Benda Islamic Boarding School and to analyze the impact of the application of these concepts to the pesantren and society.

\section{Inclusive and Exclusive Islamic Boarding School}

In general, there are two Islamic boarding school models in Indonesia, traditional Islamic boarding schools (salaf) and modern Islamic boarding schools (khalaf) (Nihwan \& Paisun, 2019). According to its types, in general, Islamic boarding schools are divided into four Islamic boarding school types, curriculum types (Arifai, 2018), characteristics types classes (Sukma, 2017), and social-multicultural capitals types (Futaqi, 2019).

This research classifies the Islamic boarding school based on their characteristics; opened Islamic boarding schools (inclusive) and closed Islamic boarding schools (exclusive). The inclusive and exclusive nature referred to in this study is not the nature of the Islamic boarding schools, which rejects development and modernity to maintain the old Islamic boarding school tradition (Basyit, 2017). But inclusive and exclusive is more about the closed or open nature of the pesantren in social interactions with communities outside the spatial layout of the Islamic boarding school settlements and their impact on related global issues and multicultural conflicts (Susanti, 2013). The differences in the nature of the Islamic boarding school, which are inclusive (open) or exclusive (open), greatly influence the spatial form of the settlement and have implications for social interaction with environmental spatial planning outside the Islamic boarding school (Yuli, 2019)

\section{The History of Traditional Islamic Boarding School}

Since the beginning of its existence in the 15th century (Hasan, 2015), pesantren has been an open (inclusive) educational institution. Islamic boarding school was an inclusive education institution. An Islamic boarding school is not only focusing on its students' education but also surrounding, through social, cultural, economic activities even in the state sector (Karimah, 2018). It means that there is a correlation between the Islamic boarding schools with a community that must be maintained by the Islamic boarding school managers (PP No.55, 2007).

This condition is certainly not easy to implement in today's era. The more students, the more protection and control functions are needed toward them. Hence, based on that condition, some Islamic boarding schools choose an exclusive concept as the most efficient way to protect their students as well as keep community recognition upon its excellences (Rieser, 2012; Syafa'at, Aimah, Ekaningsih, \& Mahbub, 2015). Efforts to increase the protection of santri are very important needs and a top priority besides the role of community empowerment in the layout of the pesantren (Foliano, Green, \& Sartarelli, 2019).

According to the background and history of both Islamic boarding school concepts, each of them has its excellences, drawbacks, and continuing impacts on each. It means an Islamic boarding school that applies a closed concept will carry out the protection of the students, security, and education quality easier. Nevertheless, the tradition of the Islamic boarding school to joining community empowerment and social interaction with the surrounding becomes limited. On the other hand, when an open concept is applied, it can maintain the Islamic boarding school's traditions like mentioned above. However, the anticipation efforts in protecting the students are difficult to be done this time.

That's why there are many Islamic boarding schools that transform their existing space concept. An opened Islamic boarding school realizes the students' protection needs to increase. On the contrary, closed Islamic boarding school have some problems with social interaction and surrounding community empowerment that are causing some issues from social gap conflicts to radicalism issues. 


\section{Al-Hikmah 2 Benda Islamic Boarding School}

Al-Hikmah 2 Benda Islamic Boarding School is located in Benda village, Sirampog, Brebes Regency, the central of Java. This Islamic boarding school is built by $\mathrm{KH}$. Suchaemi and KH. Kholil Bin Mahali in 1911. During the first period in the early period Al- Hikmah Islamic boarding school is similar to a typical traditional Islamic boarding school. Aside from delivering religious education, it also helped solve problems in the community dynamically. Economic and social issues were common issues solved by the Islamic boarding school.

In 1964, due to the school's rapid growth, the school decided to divide school into two school managements. The first one is Al-Hikmah 1 Islamic boarding school with $\mathrm{KH}$. Shodiq Suchaemi as the school principal. The first school was used for male students. The second one was Al-Hikmah 2 Islamic boarding school for female students with $\mathrm{KH}$. Masruri Abdul Mughni as the school principal. (Figure 1)

Figure 1. Al-Hikmah 2

Source: Research analysis, 2020

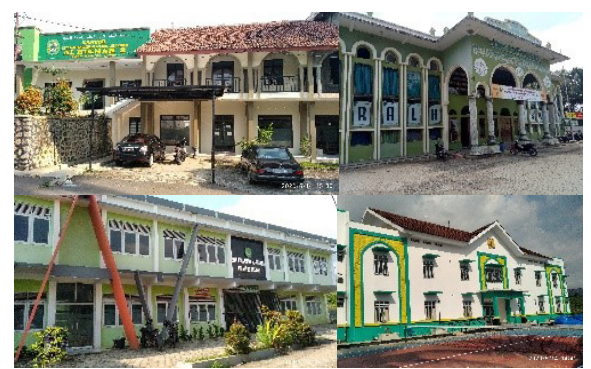

However, due to the increasing number of students and other conditions, in 1985, Islamic boarding school councils decided a new policy in which each boarding school has the right to accept students of any gender, whether male or female students in both Al-Hikmah 1 or 2 Benda Islamic Boarding Schools.

In 2006, Al-Hikmah 2 Benda Islamic Boarding School changed its characteristic from inclusive into an exclusive Islamic boarding school. The changes were a response due to the increasing number of students as well as the supporting facilities and increasing the protection. This concept changes caused some implications both in society and within the school. The school had tried to get involved in community empowerment. However, those efforts concerned only with policy, not the spatial concept.

\section{Inclusive boarding school}

Inclusive is a behaviour of a person or group that is able to adapt to other people and other different groups (Barida, 2017). According to (Persson, Åhman, Yngling, \& Gulliksen, 2015), inclusive is "The design of mainstream products and/or services that are accessible to, and usable by, as many people as "reasonably" possible on a global basis, in a wide variety of situations and to the greatest extent possible without the need for special adaptation or specialized design." The word "reasonably" show that the inclusive design understands any conditions with any backgrounds, whether it is possible or not the concept carried out.

There are several aspects of inclusive design concepts such as demographic factors (Maynard, 2018), inclusive design criteria, inclusive design principles and the process of inclusive design. Considering those aspects, the research about an inclusive and exclusive spatial concept is expected to be able to receive information about the condition and natural themes existing in the object of study sites as well as how the result of the concept becomes an anticipation response to the challenges and needs of diverse users in the future (Donahue, 2009).

Therefore, an inclusive Islamic boarding school can be a sample of an opened Islamic boarding school with different views in understanding religions along with another dimension of life with the surrounding environment, and be able to overcome some obstacles as well as accommodate the needs of the local community activities, without harming the interests and needs of the school.

\section{Exclusive Islamic Boarding School}

An exclusivity is a form of contradictory nature of inclusion. According to sociology, exclusive means a group of people who are afraid of other cultures as they are believed to have influence and can damage their existing culture. Even according (Djunaidi, Irfan, \& Safitri, 2016), it is an attitude that views beliefs, views, thoughts, as well the principle of self and group itself is the most correct. The beliefs, views, thoughts and principles of other people and groups are wrong. Exclusivity is also defined as individuals who don't want to understand the existing differences nearby by dropping groups different from themselves. Therefore, it has an impact 
Transformation of Exclusive to Inclusive Spaces: The Case of Al-Hikmah 2 Benda Islamic Boarding School, Brebes Agung Kurniawan, Nensi Golda Yuli

on the threat of inner peace, both personally and socially.

However, in a design of solution concept, exclusivity can be a pattern or a design method that can be used in a particular case that requires an "exception" so that the exclusivity problem cannot be based on only one understanding, such as accessibility, where limited accessibility become the benchmark for some researchers in assessing whether it is inclusive or exclusive.

However, it is important to look coherently at what things are behind these situations and conditions. In the case of Islamic boarding school or pesantren, the limited accessibility in a number of exclusive pesantren today, it is important to understand what is happening as well as the background to this situation, in terms of natural context its needs and conditions reality and how the researchers finally are able to offer a soluble concept.

Seeing the exclusive design concept of a building which can also be used as a reference for assessing an Islamic boarding school or pesantren with an exclusive spatial concept, there are four principles that can be used (Gemert, 2017), such as study situation, ignore conventions, prioritize identity and add a nonsense.

\section{Settlement Layout}

A settlement is a part of the environment outside a sheltered area, either in the urban or rural area, that functions as a living or residential environment and a place of activity that also supports livelihood (No.14, 2016). On the other hand, the spatial structure contains residential hubs, an infrastructure network that functions as the support of all human activities, which hierarchically have functional relationships, whether it is planned or not.

Pesantren or Islamic boarding schools as educational institutions under the state law need to make various efforts in order to achieve some planning objectives, both through planning implementation, utilization, and also space control. Throughout several considerations in the principles and residential spatial planning objectives, including integration, congeniality, harmony \& balance, sustainability, usability \& effectiveness, openness, togetherness \& partnership, public interest protection, legal certainty \& justice, and accountability.

Pesantren or Islamic boarding school as residential spatial planning and the centres of educational activities, in the settlement spatial planning process, it is also essential to consider what factors will be developed and how the development impact the area. There are three factors that need to be considered in the settlement layout according to such as elements, settlement layout design, principles of settlement layout design, and settlement layout products.

\section{Research Methods}

This research uses a naturalistic method with key instruments is the researcher itself. It is aimed that the researcher has a better understanding of inter-human interaction meaning, exploring feeling, and values contained in respondents' words or actions (Suparlan, 2014) in the object of the research studies to find the peculiarities of existing values.

The data is collected through primary data and secondary data collection with two activities, such as in-depth interview which was performed to some key figures in AlHikmah 2 Benda Islamic Boarding School and observations which related to both physical and non-physical condition at Al-Hikmah 2 Benda Islamic Boarding School.

Two units of analysis were studied, including the application of the open spatial concept period (inclusive) and closed spatial concept (exclusive), as well as the concepts' impact applied on the protection of students and their roles in community empowerment. The time limit for transforming inclusive Islamic boarding school was from 1985 to 2005, and exclusive Islamic boarding school was from 2006 to early 2020.

The process of data analysis was carried out by investigating and searching data in the fields to get the case theme along with problems that occur as well as how the themes obtained are grouped to get categorization and concepts and how they impact the boarding school and surrounding communities. 


\section{Analysis and Result}

Al-Hikmah 2 Benda Islamic Boarding School is well known as "Pondok Benda" since it is located in Benda village, while local people know it as "Pondok Wetan" since it is located in the east of Benda village. (Figure 2)

Figure 2. Location of Al-Hikmah 2 Benda Islamic Boarding School

Source: Google Earth and research analysis, 2020

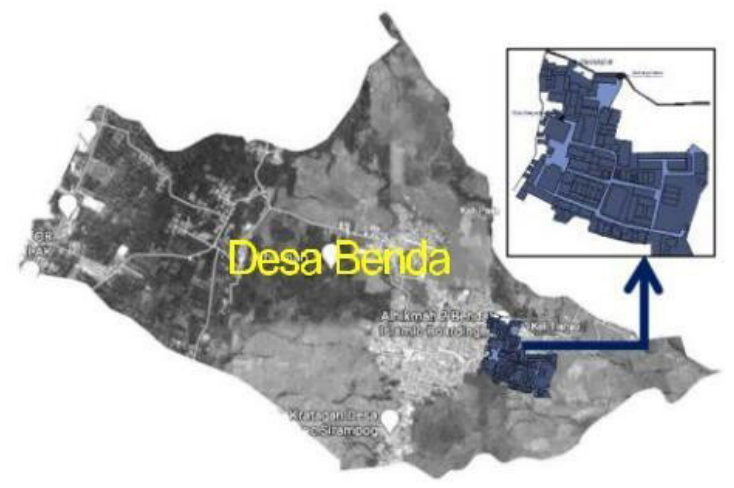

The Life of Students in Al-Hikmah 2 Benda Islamic Boarding School

Recently, the number of students at the AlHikmah 2 Benda Islamic Boarding School has reached more than 6,000 students (who live in the boarding school) and 1,500 who live outside the boarding school. The education system used by Al-Hikmah2 Benda Islamic Boarding School is a combination of the modern and traditional Islamic boarding school system, through the education provision in the form of general schools from secondary level to higher education level (Table 1). The students are also obliged to attend religious education like routine recitation schedule, sorogan, and bandongan (Table 2) as well as daily, weekly, monthly, and annual routine activities.

\section{The Community Around Al-Hikmah 2 Benda Islamic Boarding School}

The community near the Islamic boarding school is the most implicated group with the existence of the boarding school. Therefore, their existence becomes an important part, and the Islamic boarding school should pay attention to them.
Table 1. Schools at the Al-Hikmah 2 Benda Islamic boarding school

\begin{tabular}{clll}
\hline No. & Education Unit & $\begin{array}{l}\text { Educational } \\
\text { Stage }\end{array}$ & $\begin{array}{l}\text { Special Pro- } \\
\text { gram }\end{array}$ \\
\hline 1. & SMP Al-Hikmah 2 & SLTP & \\
2. & MTS Al-Hikmah 2 & SLTP & \\
3. & SMA Al-Hikmah 2 & SLTA & Tahfidz Al-Qur'an \\
4. & MAAI-Hikmah 2 & SLTA & Religious court \\
5. & SMK Wicaksana & SLTA & Agribusiness \\
6. & MMA Al-Hikmah 2 & (Muaddalah) & Yellow Book \\
7. & AKPER Al-Hikmah 2 & Diploma 3 & \\
8. & Ma'had Aly & Strata 1 & Al-Qur'an \\
9. & STAIA & Strata 1 & Ahwal \\
& & & Syahsiyyah \\
\hline
\end{tabular}

Source: Al-Hikmah 2 Benda Islamic Boarding School data

Table 2. Schedules of Islamic religious activities

\begin{tabular}{|c|c|c|c|}
\hline No. & Time & Type of activity & Students \\
\hline 1. & $03.30-04.00$ & $\begin{array}{l}\text { Tadarrus the Al- } \\
\text { Qur'an }\end{array}$ & All students \\
\hline 2. & $04.00-04.30$ & Subuh prayers & All students \\
\hline 3. & $04.30-05.45$ & Al-Qur'an recitation & All students \\
\hline \multirow[t]{7}{*}{4.} & $06.00-06.45$ & Recitation of Ta'lim & SP \& $1 \mathrm{MMA}$ \\
\hline & & Muta'lim & $1 \mathrm{SMP}, 1 \mathrm{MTS}$ \\
\hline & & Recitation of Tafsir & 2, 3 MA dan 4-5-6 \\
\hline & & Jalalain & MMA \\
\hline & & $\begin{array}{l}\text { Recitation of Bi- } \\
\text { dayatul Hidayah }\end{array}$ & $\begin{array}{l}2 \text { MMA, } 2 \text { MTS, } 2 \\
\text { SMA }\end{array}$ \\
\hline & & Pengajian Irsyadul & $\begin{array}{l}3 \text { MMA, } 3 \text { SMK } \\
\text { dan } 3\end{array}$ \\
\hline & & Ibad & SMA, Akper \\
\hline 5. & $07.00-08.00$ & Fathul Wahab & Ma'had Aly, STIAI \\
\hline \multirow[t]{3}{*}{6.} & $17.00-18.00$ & Recitation of Tafsir & Ma'had Aly, \\
\hline & & Munir & and STIAI \\
\hline & & Riyadh Al-Sholihin & $\begin{array}{l}\text { Students of Ma'had } \\
\text { Aly, Akper \& STIAI }\end{array}$ \\
\hline \multirow[t]{4}{*}{7.} & $18.30-19.30$ & Hidayat As- & $\begin{array}{l}1 \mathrm{MTS}, 1 \mathrm{MA}, 1 \\
\text { SMK }\end{array}$ \\
\hline & & Sibyan\&Yanbu'a & \& SP MMA \\
\hline & & Aj-jurumiyah & $\begin{array}{l}2 \text { MTS, } 2 \text { MA, } \\
\text { MTS, }\end{array}$ \\
\hline & & Al-Imrity & $3 \mathrm{MA}, 2 \mathrm{MMA}$ \\
\hline 8. & $20.00-21.00$ & Central recitation & All students \\
\hline
\end{tabular}

Source: Al-Hikmah 2 Benda Islamic Boarding School data

In 1985 the Al-Hikmah 2 Benda Islamic Boarding School was classified as a small type of Islamic boarding school with a number of students under 1,000 students. The area consist of about $0.5 \mathrm{Ha}$ with spatial concept integrated to the nearby community (according to $M D$ ). 
Transformation of Exclusive to Inclusive Spaces: The Case of Al-Hikmah 2 Benda Islamic Boarding School, Brebes Agung Kurniawan, Nensi Golda Yuli

"In early 1985, there were still very few students, around 700 female students, and around 150 male students. The female dormitory is located behind the kyai's house, while the male dormitory was separated in the community settlement, which the house was Mr. Husain's donation, that's why the dormitory is called the Al-Husain complex" (interview with MD in May 2020).

In terms of school management, the AlHikmah 2 Benda Islamic Boarding School has been separated from the Al-Hikmah 1 Islamic boarding school, but for educational activities, each school can go one another, which means that students from the west boarding school (Pondok Kulon) can go to Pondok Wetan (east boarding school) and vice versa until 2005.

\section{Al-Hikmah 2 Benda Islamic Boarding School 2006 To 2020 Period}

A major change of Al-Hikmah 2 Benda Islamic Boarding School's spatial concept started at the end of 2005, with the construction of Al-Hasan male's dormitory complex in order to accommodate students who could no longer be accommodated in the Al-Husain dormitory. Followed by a usage change of AlHusain male's dormitory to become a female's dormitory by changing the building orientation to the hub of the Islamic boarding school.

Nowadays, Al-Hikmah 2 Benda Islamic boarding school has a $7 \mathrm{Ha}$ land area (Figure 3 ), consisting of 64 building masses and ten open spaces, as well as other facilities.

Figure 3. Layout condition of Al-Hikmah 2 Benda Islamic boarding school 2020

Source: Research analysis, 2020

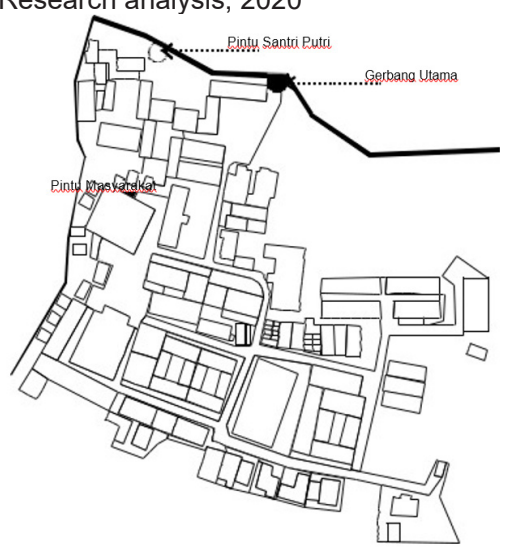

\section{Research Themes}

The results of research within several months at the research location were found nine research themes, as follows:

\section{Theme 1. Dualism function of Space in Al- Hikmah 2 Benda Islamic Boarding School}

Currently, the layout of Al-Hikmah 2 Benda Islamic Boarding School has a dualism of space function. The first function is an enclosed space for students to limit their activities in the Islamic boarding school layout. The second function is an open space for the society to do socio-economic activities in the Islamic boarding school layout. This theme is the result of observation and interviews with key person 1.

"I just carry on, and we both know keeping the mandate is very difficult, both the mandate of the founders, the parents, and the society. Either way, we should be able to walk together, even if it's not perfect, but I keep trying. One of the ways I use is to change the boarding school so that it is closed to students but open to the public".

(Interview with KHS April 2020).

The data results of observation also show that, although the layout of Al-Hikmah 2 Islamic boarding school is covered by fences and the arrangement of the mass system as an effort of Islamic boarding school to protect the students, researchers also found 12 inclusive spaces used for interaction between students and the society in Islamic boarding school layout (Figure 4).

Figure 4. Inclusive spaces in the layout of Al-Hikmah 2 Benda Islamic Boarding School

Source: Research analysis, 2020

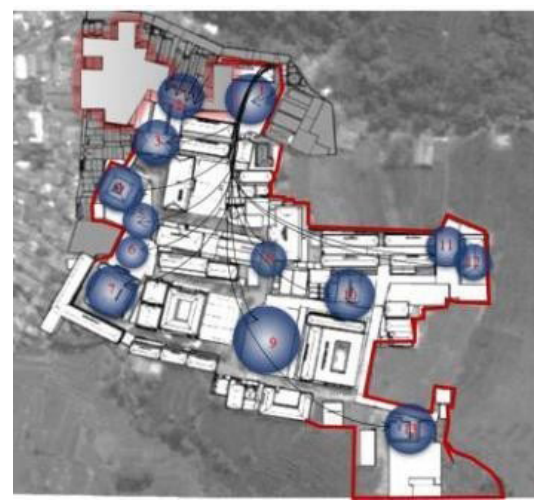


The information that the Islamic boarding school is still open to the society is also delivered by the surrounding society from the results of the following interview:

"Now, the boarding school is closed, but I can still make a living in Islamic boarding school selling behind my house".

(Interview with ML June 2020).

\section{Theme 2. The Permeability of Exclusive Spaces, Pondok Kulon and Pondok Wetan}

The terms Pondok Kulon (West Islamic boarding school) and Pondok Wetan (East Islamic boarding school) are how village society of Benda Village and its surroundings to name Al-Hikmah 2 Islamic boarding school (Pondok Wetan) and Al-Hikmah 1 Islamic boarding school (Pondok Kulon). In the previous period (before 2006th), there has been a permeability in the concept of exclusivity of Pondok Kulon and Pondok Wetan, although they have been separated in each Islamic boarding school activities cross circulation between them was still shown. As stated by MJ, teacher of AlHikmah 1 Islamic Boarding School,

"The society still call it as Pondok Kulon and Wetan until now. I've taught from the late 80 s until now in the Pondok Kulon, but it's normal. Sometimes we play badminton and other activities in Pondok Wetan."

(Interview with MJ June 2020).

The exclusivity concept of Pondok Kulon and Pondok Wetan is also applied to Islamic boarding school Al-Hikmah 2 Benda spatial, a space separation based on gender, between male students and female students. However, the permeability condition also still occurs in the exclusivity concept of Al-Hikmah 2 Benda Islamic Boarding School layout, it can be seen from the observation of cross circulation (Figure 5 ) between those two, such as male students doing Friday prayers at An-Nur mosque located in the female zone, but the high school for female students located on the side if field which is in the male zone.
Figure 5. Cross circulation of male students and female students in the spatial of AL-Hikmah 2 Benda Islamic Boarding Schoo

Source: Research analysis, 2020

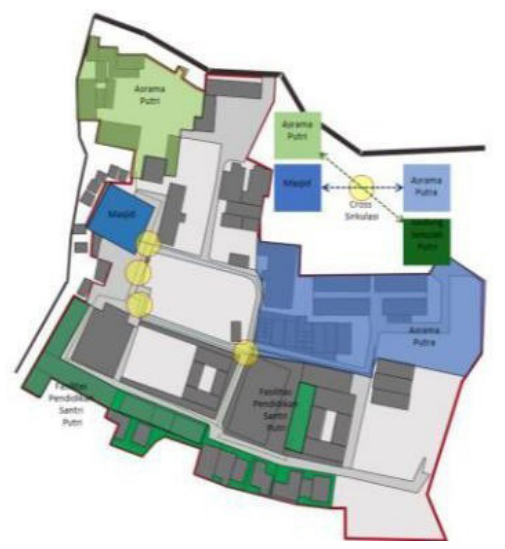

Theme 3. Fence for the protection of the security of students

The Purpose of limiting students to the outside environment of Islamic boarding school through the enclosed layout concept with its fences and mass system arrangement is an effort from Islamic boarding school to protect their students. This theme is obtained from several key persons, starting from key-person 1 .

"If the Islamic boarding school is closed, it is easier for the students. It means that if the Islamic boarding school is closed, then the protection of students will be much easier".

(Interview with KHS in April 2020)

The result of observations showed that there is a barrier in Al-Hikmah 2 Benda spatial from its surroundings, either fences or arrangement of mass. (Figure 6)

Figure 6. The spatial barrier of Islamic boarding school AlHikmah 2 Benda

Source: Research analysis, 2020

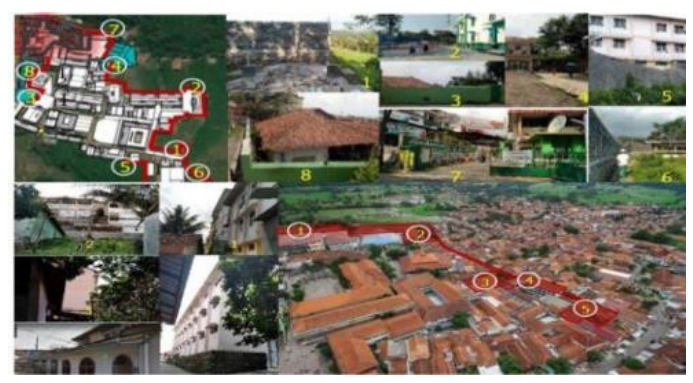

Theme 4. In and out access of Islamic boarding school

From the observation results, it can be obtained that Al-Hikmah 2 Islamic boarding school only 
Transformation of Exclusive to Inclusive Spaces: The Case of Al-Hikmah 2 Benda Islamic Boarding School, Brebes Agung Kurniawan, Nensi Golda Yuli

has three in and out access to the boarding house, including one main access for vehicles and two additional access for pedestrians. (Figure 7)

Figure 7. In and Out Access of Islamic boarding school Source: Research analysis, 2020

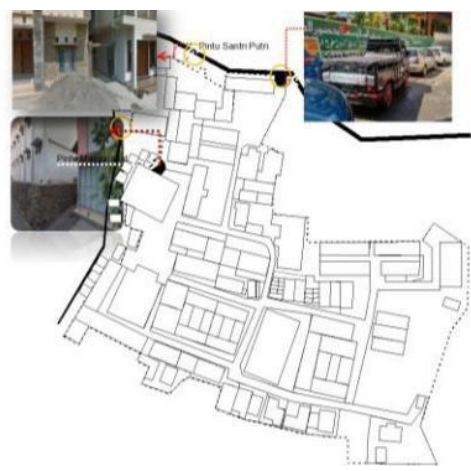

The more limitation on in and out access to boarding school starts due to the complaints from surrounding society about the number of students who skip boarding school activities but stay society people's houses. This is the result of an interview with one of the speakers:

"I and other people are complaining to an Islamic boarding school that we find students in people's homes, and do not participate in Islamic boarding school activities, so we suggest to close 4 (four) accesses that are commonly passed by them" (Interview with AMR June 2020).

The limitation on in and out access of Islamic boarding school, on one side, leads to students' disappointment, the habit of students skipping activities is easier to be controlled, as conveyed by one of the MEP students

"Leaving Islamic boarding school now is difficult, unlike it used to be, now the door is guarded, and we must have a letter if we want to go out". (Interview with MEP April 2020).

\section{Theme 5. Public Recognition Toward Of Exclusive Spaces}

The development of Islamic boarding school with the increasing number of students and the establishment of various formal educational institutions is proof that $\mathrm{Al}-\mathrm{Hikmah}$ 2 Benda Islamic Boarding Cchool is one of the educational institutions that increasingly gained the trust of the public. The enclosed concept boarding school layout with the aim of protecting students is one form of boarding school effort in maintaining public trust, such as the following interview:

"Parents feel safer to leave their children here. One of their reasons besides curriculum is also because children cannot freely exit Islamic boarding school."

(Interview with AM April 2020).

The Purpose of parents to leave the child to Islamic boarding school is not only due to the needs of public and religious education but also the needs of moral education, which they hope should be better from the home and the environment from where the parents live. Therefore, boarding school should be able to maintain and improve the existing potential as an effort to maintain the trust of parents. This is also stated by one of the female students in Al-Hikmah 2 Benda Islamic Boarding School:

"I never go out from Islamic boarding school, Sir, unless it is a holiday to go home and if there are families who come alone to invite me having a meal outside" (Interview with IR April 2020).

Another inline statement is also conveyed by one of the parents:

"It's a holiday, so the kid at home and I am who picked up to Benda yesterday, it was a strict there, so I feel safe to leave my son there" (Interview with HA June 2020).

\section{Theme 6. The Islamic Boarding School Spatial As Protection For Students And Society}

The changing of Al-Hikmah 2 Benda Islamic Boarding School is not only the efforts of Islamic boarding school in protecting the students but also against the public interests. There are some inclusive rooms in Al-Hikmah 2 Islamic boarding school layout that can be used by the public in educational activities as well as public economic activities. The development of times also demands that Islamic boarding school conform so that the existence of Islamic boarding school is always protected by facilitating the role activities of empowering society in Islamic boarding school spatial, is able to meet the current needs of parents, who want Islamic boarding school to limit their children's activities outside of boarding school activities, such as the following interview excerpts:

"The Islamic boarding school has an obligation to look after the surrounding community, but 
Journal of Architectural Research and Design Studies Volume 5 Number 1 (April 2021)

the Islamic boarding school also has the main obligation which is to educate and look after students, how this can run together, to support and care for each other. Never let the Islamic boarding school accursed as it forgets the history of establishment from society, but the public should also know the Islamic boarding school must be protected and preserved equally" (Interview with KHS April 2020)

The concept of students' protection is also stated in the statement below:

"Every year, there is a tendency of improvement regarding the number of students, I strongly agree with what caregivers say, the parents trust to the quality of education one of them by improving the students, protection, especially in the condition of this outbreak".

(Interview with Mr 17 April 2020).

\section{Theme 7. Interaction Space Behind The House Of Surrounding Communities}

There is a uniqueness in people houses of the community that are located on Islamic boarding school boundaries. The front typology of people house is similar to the common residence, but the back part of the house, which directly adjoins with boarding school, is the centre of their economic activities (Figure 8). People use a very limited space of kitchen and backyard for selling or offering services. Although the principles of inclusive design have not been fulfilled, the efforts in protecting community empowerment are still carried out by boarding school, which is specified from the results of the following interview:

"I allow people to do economic activities in Islamic boarding school either those who use their kitchen or use the PKL room, but they must take care each other, maintain the cleanliness, students, and the selling price should not burden students and the selling time must follow the rules of boarding school".

(Interview with KHS April 2020)

People who receive benefit from the concept of community empowerment from the Islamic boarding school conveys that:

"Alhamdulillah, the presence of boarding school is also a blessing for our family. We can join selling food for students using the back porch of our house, which we divided into 4 (me, my mother, sister and my brother) (Interview with MD June 2020)

Figure 8. The kitchen and back porch of the community house as a place of economic activity.

Source: Research analysis, 2020

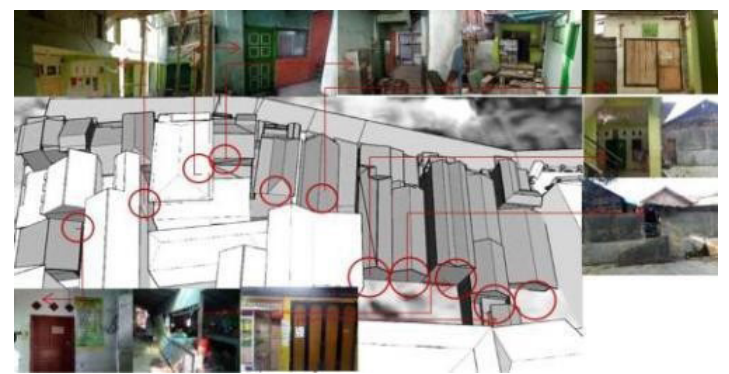

Theme 8. Street Trader Room In The Islamic Boarding School

Boarding school gives people the right of freedom to occupy some points of Street Trader rooms in boarding school, but Islamic boarding school also has obstacles with limited area to accommodate the large number of people who do economic activities in boarding school layout (Figure. 9). As one of Islamic boarding school teachers said:

"The area is limited, whereas we also have to be fair to the community, so in the meantime, we make Street Trader schedule, which is regulated by their community."

(Interview with AM in April 2020).

Figure 9. Street Trader Room in Al-Hikmah 2 Islamic boarding school

Source: Research analysis, 2020

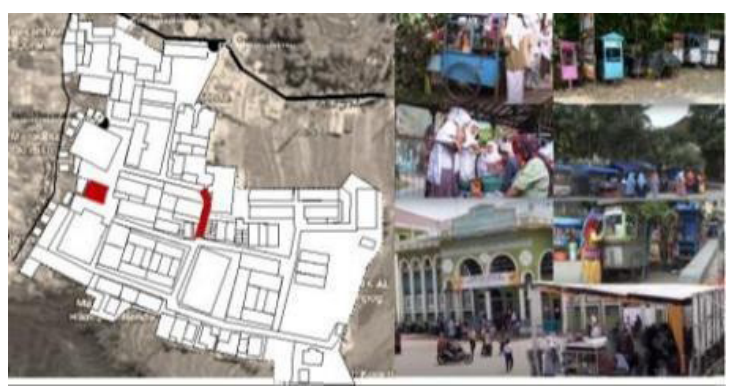

Theme 9. The Extensification Of Islamic Boarding School Through The Education Field

In the field of education, the role of empowering al-Hikmah 2 Islamic boarding school to the community can be seen from the number of non-boarding students who attend formal boarding schools, as well as a number of non-for-mall educational activities conducted in Islamic boarding school environment and elsewhere. Still, the need for area expansion 
Transformation of Exclusive to Inclusive Spaces: The Case of Al-Hikmah 2 Benda Islamic Boarding School, Brebes Agung Kurniawan, Nensi Golda Yuli

in da'wah as an empowerment role in the field of education, continues to be conducted, both through radio and through da'wah activities in social media, as in the interview below:

"Today is modern era so that boarding school should be able to follow. Teachers and family are encouraged to actively conducting da'wah either through lemprakan community or radio but should start online platform like Facebook, so those who far away can join (interview with KHS June 2020)

\section{The Results of Analysis of Concept Formation and Relationship between Concepts}

\section{Inclusive and Exclusive Islamic Boarding} School Concept

The first concept is the concept of inclusive Islamic boarding school in Al-Hikmah 2 Islamic boarding school is the running of interaction between Islamic boarding school and the surrounding community not only as proof of the role of empowerment performed by Islamic boarding school to the surrounding community, both through social, economic and educational dimensions without detriment one party and the other.

The inclusive concept of Al-Hikmah Islamic boarding school 2 is the concept of openness to the surrounding community while paying attention to the principle of inclusive design that seeks out points of exclusion and identifies situational challenges. This concept is derived from the relationship between several themes, including Theme 1, Theme 5, Theme 7, Theme 8 and Theme 9 (Figure 10).

Figure 10. The Scheme of Inclusive Concept Islamic boarding school Formation

Source: Research analysis, 2020

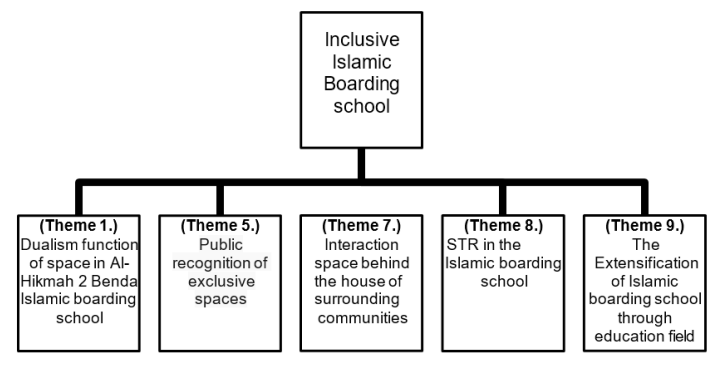

The exclusive concept of Al-Hikmah 2 Islamic boarding school is a concept of Islamic boarding school layout covered by fences and the arrangement of the mass system of boarding school to limit the environment of Islamic boarding school residence with surrounding residents and limiting the number of access available, as an effort by boarding school in protecting its students and ease of supervision. The exclusivity of Islamic boarding school aims to maintain the public trust in the excellent quality of boarding school. The exclusivity concept is also the separation between the complex of male and female students by implementing the old theme used in boarding school history called "Pondok Kulon and Pondok Wetan". The exclusive concept AlHikmah 2 Islamic boarding school is derived from the relationship between Theme 1, Theme 2, Theme 3, Theme 4, Theme 5 and Theme 6. (Figure 11)

Figure 11. The Scheme of Exclusive concept Islamic boarding school Formation

Source: Research analysis, 2020

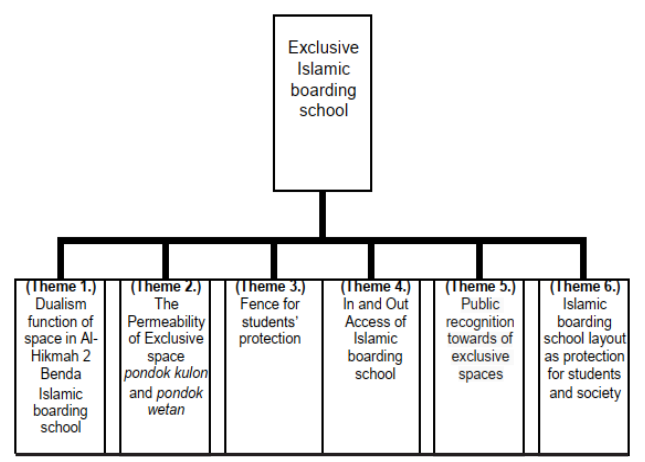

The Relationships between Two Concepts

The inclusive and exclusive concept of ALHikmah 2 Islamic boarding school is formed from the background of Islamic needs, both in its role of improving the efforts in protecting students and maintaining public trust and how boarding school can maintain the tradition in the role of community empowerment.

The dualism functions of space Al-Hikmah 2 Benda Islamic Boarding School and public recognition to exclusive space is a connecting theme of the inclusive Islamic boarding school concept and the exclusive Islamic boarding school concept of Al-Hikmah 2 Benda Islamic Boarding School. Those themes are Islamic boarding school's efforts to meet the needs and protecting the interests of both entities. Both Islamic boarding school needs to improve student's protection and the public for community empowerment performed by an Islamic boarding school, through the 
transformation of inclusive space in Al-Hikmah 2 Benda Islamic Boarding School layout.

\section{Impact Analysis of Spatial Concept Implementation}

The impact of the application concept AlHikmah 2 Benda layout will be viewed based on 2 (two) entities that exist, namely: Islamic boarding schools and outside communities.

The impact of application concept to Islamic boarding school, such as:

1. The need for efforts of students' protection is easier to perform

2. Public recognition of Islamic boarding schools' quality is protected

3. The role of boarding school towards community empowerment is not optimal

4. The presence of inclusive room in Islamic boarding school layout that requires development design layout

5. Students experience limitations in obtaining the desired of their living needs.

As for the rooms' application impact towards outside community, as follows:

1. People obtain the right in using Islamic boarding school area to carry out economic activities.

2. People can do economic activities but limited.

3. People responsibility for student's protection efforts increases

4. The parents trust increases because protection for their children is more guaranteed

5. People from outside are not free to access the boarding school layout due to limited in and out access to Islamic boarding school.

\section{Conclusion}

Based on the background in Al-Hikmah 2 Benda Islamic Boarding School, through the approach of naturalistic research methods with in-depth interviews and observations at the research location can be obtained nine themes namely: 1). Dualism functions of space in AlHikmah 2 Benda Islamic Boarding School, 2). The Permeability of exclusive spaces, Pondok Kulon and Pondok Wetan, 3). Fence for student's protection 4). In and out access to Islamic boarding school, 5). Public recognition towards exclusive space, 6). The Islamic boarding school layout to protect students and communities, 7). Interaction space behind the house of surrounding communities, 8). PKL room in the Islamic boarding school, and 9). The extensification of Islamic boarding school through education field.

The searching results of inclusive and exclusive concepts that have been used by Al- Hikmah 2 Benda Islamic Boarding School through dialogue among those themes and categorization of those themes can obtain the inclusive concept of Islamic boarding schools, the concept of exclusive Al-Hikmah 2 Benda Islamic Boarding School, namely: inclusive Islamic boarding school is how great the interaction run between Islamic boarding school and the surrounding community without detriment both parties while paying attention to inclusive design principles that seek out points of exclusion and Identify situational challenges. This concept is derived from the relationship between Theme 1, Theme 5, Theme 7, Theme 8 and Theme 9.

While the concept of exclusive Islamic boarding school Al-Hikmah 2 Islamic boarding school is a concept of Islamic boarding school layout covered by fences and the arrangement of boarding school mass to limit the residents' environment of Islamic boarding school with surrounding resident and limit the existing access as an effort from Islamic boarding school to protect students and ease in supervision. This concept is derived from Theme 1, Theme 2, Theme 3, Theme 4, Theme 5 and Theme 6.

Among nine themes obtained, the theme of dualism function space in AL-Hikmah 2 Benda Islamic Boarding School, as well as public recognition theme towards the exclusive rooms, is the connecting theme of the inclusive Islamic boarding school concept and the concept of exclusive Islamic boarding school in Al-Hikmah 2 Benda Islamic Boarding School. These themes are Islamic boarding school efforts of in fulfilling the needs and protecting interests of both entities, both the needs of Islamic boarding school in efforts to increase students' protection and the needs of people for the role of community empowerment of people carried out by boarding school.

The impact analysis results of concept implementation are measured based on two entities, Islamic boarding school and outside. It was found that the implementation concept 
Transformation of Exclusive to Inclusive Spaces: The Case of Al-Hikmah 2 Benda Islamic Boarding School, Brebes Agung Kurniawan, Nensi Golda Yuli

of exclusive rooms in Al-Hikmah 2 Benda Islamic Boarding School is the result of the development of inclusive concepts used in the previous period into the current concept of Islamic boarding school layout through the transformation of inclusive space into the layout. So, Islamic boarding school needs of as efforts to improve students' protection can be carried out and boarding school tradition of in the role of community empowerment can also be maintained, but it still needs further research on how inclusive space transformation can have an optimal impact to each entity needs.

\section{References}

Agustina, H. N. (2018). The Importance of Multicultural based Education in Indonesia to Avoid the Conflict and Issue of Disintegration. In 1st International Conference on Educational Sciences - Volume 1: ICES305-309. https://doi. org/10.5220/0007040103050309

Arifai, A. (2018). Pengembangan Kurikulum Pesantren, Madrasah Dan Sekolah. Raudhah Proud To Be Professionals: Jurnal Tarbiyah Islamiyah, 3(2), 13-20. https://doi.org/10.48094/raudhah.v3i2.27

Asmuri, A. (2017). Pendidikan multikultural (Telaah Terhadap Sistem Pendidikan Nasional dan Pendidikan Agama Islam). POTENSIA: Jurnal Kependidikan Islam, 2(1), 25. https://doi.org/10.24014/potensia. v2i1.2530

Barida, M. (2017). Inklusivitas Vs Eksklusivitas: Pentingnya Pengembangan Wawasan Kebangsaan dalam Mewujudkan Kedamaian yang Hakiki Bagi Masyarakat Indonesia. (February), The 5thURECOL Proceeding. 1403-1409.

Basyit, A. (2017). Pembaharuan model pesantren: respon terhadap modernitas. Journal Komunikasi Antar Perguruan Tinggi Agama Islam, 16(2).

Clarke, M. (2017). The Impact of Ethnic Minorities on China's Foreign Policy: The Case of Xinjiang and the Uyghur. China Report, 53(1), 1-25. https://doi. org/10.1177/0009445516677361

Cranfield, N. (2015). Boarding schools. TLS - The Times Literary Supplement, (5854), 6. https://doi. org/10.1142/9789814623797_0004

Cristol, J. (2018). United States Foreign Policy in the Middle East after the Cold
War. Retrieved from https://www.e-ir.info/ publication/conflict-and-diplomacy-in-themiddle-east-external-actors-and-regionalrivalries/

Djunaidi, A., Irfan, L. A., \& Safitri, E. (2016). Kebangkitan Masjid Kampus Di Yogyakarta: Eksklusif Atau Inklusif?. Millah, 15(2), 283298. https://doi.org/10.20885/millah.vol15. iss2.art5

Donahue, S. (2009). Inclusive Design 2 . 0 evolving the approach and meeting new challenges. Include 2009, (April).

Foliano, F., Green, F., \& Sartarelli, M. (2019). Away from home, better at school. The case of a British boarding school. Economics of Education Review, 73, $101911 . \quad$ https://doi.org/10.1016/J. ECONEDUREV.2019.101911

Hasan, M. (2015). Perkembangan Pendidikan Pesantren Di Indonesia. TADRIS: Jurnal Pendidikan Islam, 10(1), 55. https://doi. org/10.19105/jpi.v10i1.638

Karimah, U. (2018). Pondok Pesantren, dan Tujuan Pendidikan. Misykat, 03(01), 137154.

Kusnadi, E., Sobur, K., \& Aziz, A. (2017). in Between Islamic Boarding School: a Study of Al-Mubarok Al-Islam Within the Social Changes of Seberang Kota Jambi. Addin, 11(1), 101. https://doi.org/10.21043/addin. v11i1.1920

Li, D. (2013). Policy and Practice in Multicultural Education A case study of a multi-ethnic pre-university college. (May). Retrieved from http://www.duo.uio.no/

Martin, A. J., Papworth, B., Ginns, P., \& Liem, G. A. D. (2014). Boarding School, Academic Motivation and Engagement, and Psychological Well-Being: A LargeScale Investigation. American Educational Research Journal, 51(5), 1007-1049. https:// doi.org/10.3102/0002831214532164

Maynard, C. (2018). All-Inclusive Design: How Architects Build for Humanity from Cradle to Grave. Retrieved from https:// hmcarchitects.com/news/all-inclusivedesign-how-architects-build-for-humanityfrom-cradle-to-grave-2018-12-21/

Muhaemin Latif. (2016). Multicultural education in Islamic boarding school. Journal of Islamic Civilization in Southeast Asia (JICSA), 5 (2). https://doi.org/10.24252/ jicsa.v5i2a6

Nakaya, A. (2018). Overcoming ethnic conflict through multicultural education: The case of West Kalimantan, Indonesia. International 
Journal of Multicultural Education, 20(1), 118-137. https://doi.org/10.18251/ijme. v20i1.1549

Nihwan, M., \& Paisun. (2019). Tipologi Pesantren (Mengkaji Sistem Salaf dan Modern). JPIK 2(1), 59-81.

Persson, H., Åhman, H., Yngling, A. A., \& Gulliksen, J. (2015). Universal design, inclusive design, accessible design, design for all: different concepts-one goal? On the concept of accessibility-historical, methodological and philosophical aspects. Universal Access in the Information Society, 14(4), 505-526. https://doi.org/10.1007/ s10209-014-0358-z

PP No.55. (2007). Pasal 1 Ayat 4.

Rieser, R. (2012). How to order : Implementing Inclusive Education.

Sukma, M. (2017). Lembaga Pendidikan Pembentukan Karakter. Al-Tadzkiyyah: Jurnal Pendidikan Islam, 8, 85-103.

Suparlan, P. (2014). Paradigma Naturalistik dalam Penelitian Pendidikan: Pendekatan Kualitatif dan Penggunaannya. Antropologi Indonesia, Vol. 0. https://doi.org/10.7454/ ai.v0i53.3323

Susanti, R. D. (2013). MENGUAK MULTIKULTURALISME DI PESANTREN : Telaah atas Pengembangan Kurikulum. 7(1), 179-194.

Syafa'at, A. K., Aimah, S., Ekaningsih, L. A. F., \& Mahbub. (2015). Strategi Pengembangan Pondok Pesantren Dalam Era Globalisasi Di Kabupaten Banyuwangi. Inferensi, 6(2), 245. https://doi.org/10.18326/infsl3. v8i1.245-269

Yuli. N. G. (2019). The spatial value of local houses around Islamic Boarding School in Mlangi Moslem settlements, Yogyakarta, Indonesia. MATEC Web of Conferences, Vol 277, pg 02020. https://doi. org/10.1051/matecconf/201927702020

Yuli, N. G., Haningsih, S., \& Adikrishna, R. (2011). The Common Room Design of Islamic Boarding School: A Preliminary Research in Yogyakarta Islamic Boarding School. International Journal of Engineering \& Technology, 11(04), 127-134. Retrieved from https://www.semanticscholar.org/ paper/The-Common-Room-Design-ofIslamic-Boarding-School-\%3A-Yuli-Haning sih/44cb24bf76f2ecf2890d68af4e31250d2 72e9ff6 